\author{
Journal of Chemical, Biological and Physical Sciences

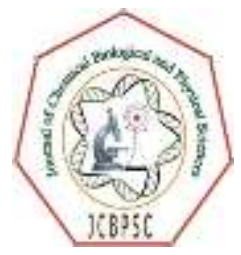 \\ An International Peer Review E-3 Journal of Sciences \\ Available online atwww.jcbsc.org \\ Section B: Biological Sciences \\ Research Article
}

\title{
Effect of nitrogen and potassium on post harvest stored insect pest infestation of two garlic genotypes
}

\author{
Md. Shamim ${ }^{1}$ and M. A. Rahim ${ }^{2}$ \\ ${ }^{1}$ Additional Deputy Director (Crop) Dinajpur District, Department of Agricultural Extension, \\ Ministry of Agriculture, Govt. of the People's Republic of Bangladesh \\ ${ }^{2}$ Department of Horticulture, Bangladesh Agricultural University, Mymensingh, Bangladesh
}

Received: 07 February 2019; Revised: 25 February 2019; Accepted: 04 March 2019

\begin{abstract}
An experiment was conducted to study the effect of nitrogen and potassium on insect pest infestation of two stored garlic varieties. The garlic genotypes were grown at the of Spices Research Center, Bogra during November 2000 to March 2001 and stored in the department of Horticulture of Bangladesh Agricultural University, Mymensingh, Bangladesh during the period from April , 2001 to October, 2001. The experiment consists of two garmplasm i.e. Accession G19 and G20 with four levels of nitrogen $(0,100,200,300 \mathrm{~kg} \mathrm{~N} / \mathrm{ha})$ and potassium $\left(0,100,200,300 \mathrm{~kg} \mathrm{~K}_{2} \mathrm{O} / \mathrm{ha}\right)$. The three factorial experiment was laid out in a randomized complete block design with three replications. Results demonstrated that there was significant variation present among the studied treatments. The study result showed that the maximum percentage of insect infested bulbs (21.28) was observed from the combination of accession $\mathrm{G}_{20}$ with $0 \mathrm{~kg} \mathrm{~N} / \mathrm{ha}$ and $0 \mathrm{~kg} \mathrm{~K}_{2} \mathrm{O} / \mathrm{ha}$, whereas the minimum percentage was obtained from $\mathrm{G}_{19}$ with $100 \mathrm{~kg} \mathrm{~N} / \mathrm{ha}$ and $200 \mathrm{~kg} \mathrm{~K} 2 \mathrm{O} / \mathrm{ha}$ and $\mathrm{G}_{19}$ with $200 \mathrm{~kg} \mathrm{~N} / \mathrm{ha}$ and $2000 \mathrm{~kg} \mathrm{~K} 2 \mathrm{O} / \mathrm{ha}$.
\end{abstract}

Key words: Garlic, Nitrogen, Potassium, Post harvest quality 


\section{INTRODUCTION}

Garlic (Allium sativum L.) is one of the most important bulbous vegetable crop and commonly used as a spice or in the medicinal purposes. It took place after onion with respect to use. Central Asia and later spread to Mediterranean region may be the center of origin of this aromatic herbaceous plant ${ }^{1,2}$. It is primarily consumed for its unique flavor and ability to enhance the flavor of other foods ${ }^{3}$. Anti carcinogenic, microbial and insecticidal properties are also present in garlic. Due to the presence of sulphur containing compound diallyl disulphide garlic is pungent. And because of its pungent flavor, it is used mainly as a spice, seasoning and flavoring for foodstuff involving both green tops and bulbs. In the Rabi season Garlic is grown all over Bangladesh and consumed by most of the people ${ }^{4}$. In Bangladesh, nearly 425401 MT bulbs of garlic were produced in 2016-17 from 163733 acres of land ${ }^{5}$ . Though the production of garlic is increasing day day the average production $(2.59 \mathrm{mt} / \mathrm{acre})$ of Bangladesh is low compared to world per acre production. That's why Bangladesh has to depend on import of garlic from other exporter countries to meet their demand. But this problem can be solved by using proper nutrient management practices (proper doses of different fertilizers) and also by using of high yielding variety with proper storage facility. For improving productivity and quality of crop, soil nutrient management plays a significant role 6 .

Garlic in spite of being vegetatively propagated crop, possesses a wide range of variability in bulb storability and yield traits. The post-harvest losses in fruits and vegetables range from $24-40 \%$ across the globe $^{7}$ or even greater reaching up to $50 \%$ in developing tropical countries ${ }^{8}$. About $25-50 \%$ Postharvest losses of fresh fruits and vegetables are called in Bangladesh ${ }^{9}$, where it is only 5-25\% in developed countries ${ }^{10}$. Garlic is highly susceptible to agro-techniques and environmental conditions. As a nutrient exhaustive crop garlic removes a good amount of nitrogen, phosphorus and sulphur from the soil.

To improve growth, yield and marketable proportions as well as quality of the crop uptake of sufficient nutrient by the garlic crop are important ${ }^{11}$. Quality of bulb crops can be affected by mineral nutrition, irrigation schedule or rainfall ${ }^{12}$, cultivar differences and the use of growth factors i.e. plant essential nutrient contents ${ }^{13}$. In post-harvest storage several factors contribute to storage of quality garlic bulbs like stage of bulb development, premature defoliation, skin integrity and conditions during growth, maturation, harvesting, curing and storage ${ }^{14}$. Appropriate use of growth promoters (essential nutrient contents) my led to proper storage condition of garlic.

Nitrogen, phosphorus, sulphur and potassium are the principal plant nutrients required in much greater quantities and are important component of proteins, enzymes, sugars and vitamins in plants. Nitrogen is essential for the synthesis of chlorophyll, enzymes and proteins. The growth and yield of Garlic plants were improved by potassium application ${ }^{15-18}$. From a combination of soil and external fertilizers to ensure optimum growth, yields and quality plants demand for nutrients can be satisfied. To increase yield of bulbs top dressing of nutrients are known, however high levels of fertilizers reduce the storage life of bulbs ${ }^{19}$. Increasement of physiological disorders of crops after harvest due to deficiencies of some minerals and toxicity of others which will lead to a negative effect on the quality of crops $^{20}$ those affect the storage quality badly. For this reason this study to find out the suitable rate of different rates of nitrogen and potassium fertilizer for post-harvest storage quality of garlic bulbs. 


\section{MATERIALS AND METHOD}

2.1. Study area:The garlic genotypes was grown at the of Spices Research Center, Bogra during November 2000 to March 2001 and stored in the department of Horticulture of Bangladesh Agricultural University, Mymensingh, Bangladesh during the period from April , 2001 to October, 2001.

2.2. Study design:The three factorial experiment was laid out in a randomized complete block design with three replications.

2.3. Production procedure: In each block, the land was divided into 32 plots and each plot size was $1.2 \mathrm{~m} \times 1.0 \mathrm{~m}$. The space between the blocks and plots were $1.0 \mathrm{~m}$ and $350 \mathrm{~cm}$, respectively. With the use of a pointed stick the selected accessions of garlic cloves were placed at a depth of $2 \mathrm{~cm}$ in the soil. The organic matter content of the experimental plot was low and the soil was acidic in nature. The total $\mathrm{N}$ and exchangeable $\mathrm{K}$ status of the soil were also low. Ten days before the clove planting, the entire quantity of well decomposed cow dung and TSP @ 15 ton and $120 \mathrm{~kg} \mathrm{ha}^{-1}$ were applied at final land preparation. Urea and MoP were applied as a source of nitrogen and potassium at two split date (30 and 60 days after planting) as top dressing. Garlic seeds were planted in the first week of November. Intercultural operations were done as per required. After harvest stored data on different studied character were recorded as per necessary.

2.4. Statistical analysis: The mean for all treatments were calculated and the analyses of variances for most of the characters under consideration were performed by ' $\mathrm{f}$ "variance test. The significance of the difference between pairs of means was expressed as least significance different (LSD) test taking the probability level $5 \%$ as the minimum unit of significance .

Table 1: Treatments of the experiment

$\begin{array}{lll}\text { Factor A: } & \text { Factor B: } & \text { Factor C: }\end{array}$

Two garmplasm Four levels of nitrogen

Four levels of potassium

Accession $\mathrm{G}_{19}$

$\mathrm{N}_{0}: 0 \mathrm{k} \mathrm{N} \mathrm{ha}^{-1}$ (control)

$\mathrm{K}_{0}: 0 \mathrm{~kg} \mathrm{~K}_{2} \mathrm{O}$ ha $^{-1}$ (control)

Accession $\mathrm{G}_{20}$

$$
\begin{aligned}
& \mathrm{N}_{1}: 100 \mathrm{~kg} \mathrm{~N} \mathrm{ha}^{-1} \\
& \mathrm{~N}_{2}: 200 \mathrm{~kg} \mathrm{~N} \mathrm{ha}^{-1} \\
& \mathrm{~N}_{3}: 300 \mathrm{~kg} \mathrm{~N} \mathrm{ha}^{-1}
\end{aligned}
$$$$
\mathrm{K}_{1}: 100 \mathrm{~kg} \mathrm{~K}_{2} \mathrm{O} \mathrm{ha}^{-1}
$$$$
\mathrm{K}_{2}: 200 \mathrm{~kg} \mathrm{~K}_{2} \mathrm{O} \mathrm{ha}{ }^{-1}
$$

$\mathrm{K}_{3}: 300 \mathrm{~kg} \mathrm{~K} \mathrm{O}$ ha $^{-1}$

\section{RESULTS AND DISCUSSION}

The Percentage of insect infested bulbs were insignificantly influenced by garmplasm at different periods of storage except at 150 and 180 days of storage (Table 2). Infestation by insect of garlic bulbs started after about one month of storage, and continued throughout the whole storage period but it varies in degrees. At 180 days of storage, the higher percentage of insect infested bulbs (9.77) were founded in accession $\mathrm{G}_{20}$ whereas the lower percentage of insect infested bulbs (6.80) was found in accession $\mathrm{G}_{19}$ (Table 3). The variation in percentage of inspected bulbs between the garmplasm might 
be due to their genetic potentialities. Infestation of garlic bulbs was caused by cigarette beetle (Lasioderma serricorne) and garlic borer (not identified) during storage period.

Table 2 : Analysis of variance on the data on the percentage of insect infested garlic bulbs at different period of storage as influenced by garplasm, nitrogen and potassium

\begin{tabular}{ccccccc}
\hline Source of & Degree of freedom & \multicolumn{5}{c}{ Mean square } \\
\cline { 3 - 7 } variation & $(\mathbf{d f})$ & \multicolumn{5}{c}{ Storage period in days } \\
\cline { 3 - 7 } & & $\mathbf{6 0}$ & $\mathbf{9 0}$ & $\mathbf{1 2 0}$ & $\mathbf{1 5 0}$ & $\mathbf{1 8 0}$ \\
\cline { 3 - 7 } & 2 & 0.00 & 0.99 & 2.28 & 1.94 & 0.24 \\
Block & 31 & $3.35^{* *}$ & $15.80^{* *}$ & $43.49 * *$ & $94.21^{* *}$ & $95.61^{* *}$ \\
Treatment & 1 & 2.34 & 12.95 & 22.87 & $261.53^{* *}$ & $211.91^{* *}$ \\
Garmplasm (A) & 3 & 4.43 & $21.89 * *$ & $103.07 * *$ & $363.89^{* *}$ & $369.51^{* *}$ \\
Nitrogen (B) & 3 & 0.96 & 9.92 & 17.42 & 18.16 & 12.69 \\
A X B & 3 & 3.04 & $70.12^{* *}$ & $237.07 * *$ & $353.32^{* *}$ & $355.64 * *$ \\
Potassium (C) & 3 & 2.34 & 2.91 & 11.68 & 13.26 & 19.40 \\
A X C & 9 & 2.11 & 9.84 & $14.39 * *$ & $20.98^{*}$ & $24.20^{*}$ \\
B X C & 9 & 5.58 & 8.21 & 9.65 & $24.92^{*}$ & $29.16^{* *}$ \\
A X B X C & 62 & 1.613 & 6.675 & 6.439 & 9.975 & 9.180 \\
Error & & & &
\end{tabular}

Different levels of nitrogen significantly influenced on percentage of insect infested bulbs at different periods of storage except at 60 days of storage (Table 2). From the results it was observed that the highest percentage of insect infested bulbs (13.52) was found in bulbs grown with $300 \mathrm{~kg} \mathrm{~N} / \mathrm{ha}$, whereas the lowest (5.04) was found in $100 \mathrm{~kg} \mathrm{~N} / \mathrm{ha}$ at 180 days of storage (Table 3). The percentage of insect infested bulbs were increased significantly with the increasing doses of nitrogen from 0 to $300 \mathrm{~kg} \mathrm{~N} / \mathrm{ha}$. The highest percentage of insect infested bulbs observed at $300 \mathrm{~kg} \mathrm{~N} / \mathrm{ha}$, possibly due to more succulent of the bulbs which might be contributing to favorable conditions for more infestation by insect. Different levels of potassium also significantly influenced on percentage of insect infested bulbs at different periods of storage except at 60 days of storage (Table 2).

At 180 days of storage, the highest percentage of insect infested bulbs (13.43) was found in bulbs grown with $0 \mathrm{~kg} \mathrm{~K}_{2} \mathrm{O} / \mathrm{ha}$, and the lowest percentage of insect infested bulbs (4.46) was found from the treatment $200 \mathrm{~K}_{2} \mathrm{O} /$ ha (Table 3). The bulbs obtained from $0 \mathrm{~kg} \mathrm{~K}_{2} \mathrm{O} /$ ha fertilized crop were relatively immature, more succulent and had low dry matter content, which probably caused more infestation in storage by the insect. There was no significant variation between the interaction effect of garmplasm and nitrogen on percentage of insect infested bulbs at different periods of storage (Table 2). But their combined effect was found to be significant in respect (Table 3). The minimum percentage of insect infested bulbs (15.57) was recorded in accession 20 with $300 \mathrm{~kg} \mathrm{~N} / \mathrm{ha}$ at 180 days of storage and the minimum percentage of insect infested bulbs (3.79) was recorded in accession ${ }_{19}$ with $200 \mathrm{~kg} \mathrm{~N} / \mathrm{ha}$ 
treatment combination. The interaction effects of garmplasm and potassium on percentage of insect infested bulbs was found to be insignificant at different periods of storage (Table 2).

Table 3: Effect of garmplasm, nitrogen and potassium on cumulative loss of insect infested bulbs (\%) at different periods of storage

\begin{tabular}{|c|c|c|c|c|c|}
\hline \multirow[t]{2}{*}{ Treatment Combinations } & \multicolumn{5}{|c|}{ Storage period in days } \\
\hline & 60 & 90 & 120 & 150 & 180 \\
\hline $\mathrm{G}_{19}$ & 0.31 & 1.27 & 3.15 & 6.47 & 6.80 \\
\hline $\mathrm{G}_{20}$ & 0.63 & 2.00 & 4.13 & 9.77 & 9.77 \\
\hline LSD (0.05) & NS & NS & NS & 1.29 & 1.24 \\
\hline $\operatorname{LSD}(0.01)$ & - & - & - & 1.71 & 1.64 \\
\hline \multicolumn{6}{|l|}{ Levels of nitrogen } \\
\hline $\mathrm{N}_{0}$ & 0.83 & 2.75 & 4.88 & 8.41 & 9.07 \\
\hline $\mathrm{N}_{1}$ & 0.00 & 0.83 & 1.88 & 5.04 & 5.04 \\
\hline $\mathrm{N}_{2}$ & 0.21 & 0.84 & 1.89 & 5.52 & 5.12 \\
\hline $\mathrm{N}_{3}$ & 0.83 & 2.11 & 5.92 & 13.52 & 13.52 \\
\hline $\operatorname{LSD}(0.05)$ & NS & 1.49 & 1.46 & 1.82 & 1.75 \\
\hline $\operatorname{LSD}(0.01)$ & - & - & 1.95 & 2.42 & 2.33 \\
\hline \multicolumn{6}{|l|}{ Levels of Potassium } \\
\hline $\mathrm{K}_{0}$ & 0.83 & 3.59 & 8.00 & 13.43 & 13.43 \\
\hline $\mathrm{K}_{1}$ & 0.00 & 0.00 & 1.04 & 6.59 & 6.50 \\
\hline $\mathrm{K}_{2}$ & 0.42 & 0.42 & 1.67 & 4.46 & 4.46 \\
\hline $\mathrm{K}_{3}$ & 0.63 & 2.53 & 3.83 & 8.09 & 8.75 \\
\hline $\operatorname{LSD}(0.05)$ & NS & 1.49 & 1.46 & 1.85 & 1.75 \\
\hline $\operatorname{LSD}(0.01)$ & - & 1.98 & 1.95 & 2.42 & 2.33 \\
\hline \multicolumn{6}{|l|}{ Garmplasm x Nitrogen } \\
\hline $\mathrm{G}_{19} \mathrm{~N}_{\mathrm{o}}$ & 0.83 & 2.96 & 4.67 & 5.99 & 7.31 \\
\hline $\mathrm{G}_{19} \mathrm{~N}_{1}$ & 0.00 & 2.42 & 1.17 & 4.63 & 4.63 \\
\hline $\mathrm{G}_{19} \mathrm{~N}_{2}$ & 0.00 & 0.83 & 2.08 & 3.79 & 3.79 \\
\hline $\mathrm{G}_{19} \mathrm{~N}_{3}$ & 0.42 & 0.86 & 4.19 & 11.47 & 11.47 \\
\hline $\mathrm{G}_{20} \mathrm{~N}_{\mathrm{o}}$ & 0.83 & 2.54 & 5.09 & 10.82 & 10.82 \\
\hline $\mathrm{G}_{20} \mathrm{~N}_{1}$ & 0.00 & 1.25 & 2.08 & 5.46 & 5.46 \\
\hline $\mathrm{G}_{20} \mathrm{~N}_{2}$ & 0.42 & 0.86 & 1.69 & 7.24 & 7.24 \\
\hline $\mathrm{G}_{20} \mathrm{~N}_{3}$ & 1.25 & 3.36 & 7.66 & 15.57 & 15.57 \\
\hline $\operatorname{LSD}(0.05)$ & 1.04 & 2.11 & 2.07 & 2.58 & 2.47 \\
\hline $\operatorname{LSD}(0.01)$ & 1.38 & 2.80 & 2.75 & 3.43 & 2.29 \\
\hline \multicolumn{6}{|l|}{ Garmplasm x Potassium } \\
\hline $\mathrm{G}_{19} \mathrm{~K}_{\mathrm{o}}$ & 0.42 & 3.36 & 7.98 & 10.69 & 10.69 \\
\hline $\mathrm{G}_{19} \mathrm{~K}_{1}$ & 0.00 & 0.00 & 1.25 & 5.04 & 5.04 \\
\hline $\mathrm{G}_{19} \mathrm{~K}_{2}$ & 0.00 & 0.00 & 0.42 & 3.38 & 3.38 \\
\hline $\mathrm{G}_{19} \mathrm{~K}_{3}$ & 0.83 & 1.71 & 2.96 & 6.78 & 8.10 \\
\hline $\mathrm{G}_{20} \mathrm{~K}_{\mathrm{o}}$ & 1.25 & 3.82 & 8.03 & 16.17 & 16.17 \\
\hline $\mathrm{G}_{20} \mathrm{~K}_{1}$ & 0.00 & 0.00 & 0.83 & 7.96 & 7.96 \\
\hline $\mathrm{G}_{20} \mathrm{~K}_{2}$ & 0.83 & 0.83 & 2.96 & 5.55 & 5.55 \\
\hline $\mathrm{G}_{20} \mathrm{~K}_{3}$ & 0.42 & 3.36 & 4.70 & 9.41 & 9.41 \\
\hline $\operatorname{LSD}(0.05)$ & 1.04 & 2.11 & 2.07 & 2.58 & 2.47 \\
\hline $\operatorname{LSD}(0.01)$ & 1.38 & 2.80 & 2.75 & 3.43 & 2.29 \\
\hline
\end{tabular}


However, the combined effect of garmplasm and potassium was found to be significant in this respect (Table 3). At 180 days of storage, the highest percentage of insect infested bulbs (16.17) was found from the combination of accession20 with $0 \mathrm{~kg} \mathrm{~K}_{2} \mathrm{O} /$ ha and the lowest (3.38) was found from the

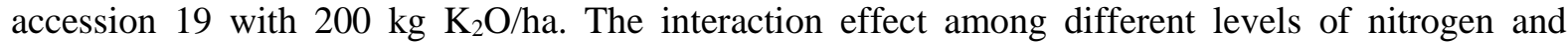
potassium showed significant variation at 120,150 and 180 days of storage but showed insignificant variation at 60 and 90 days of storage (Table 2). However, their combined effect was found to be significant in this respect (Table 4). At 180 days of storage, the maximum percentage of insect infested bulbs (16.66) was found from the treatment combination $0 \mathrm{~kg} N / \mathrm{ha}$ with $0 \mathrm{~kg} \mathrm{~K} \mathrm{~K}_{2} \mathrm{O} / \mathrm{ha}$ followed by the combination of $300 \mathrm{~kg} \mathrm{~N} / \mathrm{ha}$ with $0 \mathrm{~kg} \mathrm{~K} \mathrm{~K}_{2} \mathrm{O} / \mathrm{ha}$ (16.61), whereas the minimum percentage (0.83) was observed from $100 \mathrm{~kg} \mathrm{~N} / \mathrm{ha}$ with $200 \mathrm{~kg} \mathrm{~K} 2 \mathrm{O} / \mathrm{ha}$; and $200 \mathrm{~kg} \mathrm{~N} / \mathrm{ha}$ with $200 \mathrm{~kg}$ $\mathrm{K}_{2} \mathrm{O} /$ ha treatment combination. There was no significant interaction effect of nitrogen, potassium and garmplasm on percentage of insect infested bulbs at 90 and 120 days of storage, but showed significant variation at 60,150 and 180 days of storage (Table 2). However, their combined effect in this respect was found to be significant (Table 5). At 180 days of storage, the highest percentage of insect infested bulbs (21.28) was recorded in the treatment combination of accession $\mathrm{G}_{20}$ with $0 \mathrm{~kg}$ $\mathrm{N} / \mathrm{ha}$ and $0 \mathrm{~kg} \mathrm{~K} \mathrm{~K}_{2} \mathrm{O} / \mathrm{ha}$ followed by $\mathrm{G}_{20}$ with $300 \mathrm{~kg} \mathrm{~N} / \mathrm{ha}$ and $0 \mathrm{~kg} \mathrm{~K}_{2} \mathrm{O} / \mathrm{ha}$ (19.43) and no infestation was recorded in accession $\mathrm{G}_{19}$ with $100 \mathrm{~kg} \mathrm{~N} / \mathrm{ha}$ and $200 \mathrm{~kg} \mathrm{~K}_{2} \mathrm{O} / \mathrm{ha}$ and accession 19 with $200 \mathrm{~kg} \mathrm{~N} / \mathrm{ha}$ and $200 \mathrm{~kg} \mathrm{~K} 2 \mathrm{O} /$ ha treatment combination.

Table 4: Combined effect of nitrogen and potassium on cumulative loss of insect infested bulbs (\%) at different periods of storage

\begin{tabular}{cccccc}
\hline Treatment combinations & \multicolumn{5}{c}{ Storage period in days } \\
\cline { 2 - 6 } & $\mathbf{6 0}$ & $\mathbf{9 0}$ & $\mathbf{1 2 0}$ & $\mathbf{1 5 0}$ & $\mathbf{1 8 0}$ \\
\hline $\mathrm{N}_{\mathrm{o}} \mathrm{K}_{\mathrm{o}}$ & 1.67 & 5.92 & 10.17 & 16.66 & 16.66 \\
$\mathrm{~N}_{\mathrm{o}} \mathrm{K}_{1}$ & 0.00 & 0.00 & 0.00 & 4.17 & 4.17 \\
$\mathrm{~N}_{\mathrm{o}} \mathrm{K}_{2}$ & 0.00 & 0.00 & 1.67 & 4.25 & 4.25 \\
$\mathrm{~N}_{\mathrm{o}} \mathrm{K}_{3}$ & 1.67 & 5.09 & 7.67 & 8.56 & 11.19 \\
$\mathrm{~N}_{1} \mathrm{~K}_{\mathrm{o}}$ & 0.00 & 1.67 & 5.83 & 9.25 & 9.25 \\
$\mathrm{~N}_{1} \mathrm{~K}_{1}$ & 0.00 & 0.00 & 0.00 & 4.17 & 4.17 \\
$\mathrm{~N}_{1} \mathrm{~K}_{2}$ & 0.00 & 0.00 & 0.00 & 0.83 & 0.83 \\
$\mathrm{~N}_{1} \mathrm{~K}_{3}$ & 0.00 & 1.67 & 1.67 & 5.92 & 5.92 \\
$\mathrm{~N}_{2} \mathrm{~K}_{\mathrm{o}}$ & 0.83 & 3.38 & 5.88 & 11.19 & 11.90 \\
$\mathrm{~N}_{2} \mathrm{~K}_{1}$ & 0.00 & 0.00 & 0.83 & 5.00 & 5.00 \\
$\mathrm{~N}_{2} \mathrm{~K}_{2}$ & 0.00 & 0.00 & 0.00 & 0.83 & 0.83 \\
$\mathrm{~N}_{2} \mathrm{~K}_{3}$ & 0.00 & 0.00 & 0.83 & 5.04 & 5.04 \\
$\mathrm{~N}_{3} \mathrm{~K}_{\mathrm{o}}$ & 0.83 & 3.38 & 10.13 & 16.61 & 16.61 \\
$\mathrm{~N}_{3} \mathrm{~K}_{1}$ & 0.00 & 0.00 & 3.33 & 12.68 & 12.68 \\
$\mathrm{~N}_{3} \mathrm{~K}_{2}$ & 1.67 & 1.67 & 5.09 & 11.93 & 11.93 \\
$\mathrm{~N}_{3} \mathrm{~K}_{3}$ & 0.83 & 3.38 & 5.14 & 12.86 & 12.86 \\
$\mathrm{LSD}(0.05)$ & 1.47 & 2.98 & 2.93 & 3.65 & 3.50 \\
$\mathrm{LSD}(0.01)$ & 1.95 & 3.97 & 3.90 & 4.85 & 4.65 \\
\hline
\end{tabular}


Table 5: Combined effect of garplasm, nitrogen and potassium on insect infested bulbs (\%) at different periods of storage

\begin{tabular}{|c|c|c|c|c|c|}
\hline \multirow[t]{2}{*}{ Treatment combination } & \multicolumn{5}{|c|}{ Storage period in days } \\
\hline & 60 & 90 & 120 & 150 & 180 \\
\hline $\mathrm{G}_{19} \mathrm{~N}_{\mathrm{o}} \mathrm{K}_{\mathrm{o}}$ & 0.00 & 5.00 & 10.17 & 12.03 & 12.03 \\
\hline $\mathrm{G}_{19} \mathrm{~N}_{\mathrm{o}} \mathrm{K}_{1}$ & 0.00 & 0.00 & 0.00 & 3.33 & 3.33 \\
\hline $\mathrm{G}_{19} \mathrm{~N}_{\mathrm{o}} \mathrm{K}_{2}$ & 0.00 & 0.00 & 0.00 & 1.67 & 1.67 \\
\hline $\mathrm{G}_{19} \mathrm{~N}_{\mathrm{o}} \mathrm{K}_{3}$ & 3.333 & 6.84 & 8.51 & 6.94 & 12.21 \\
\hline $\mathrm{G}_{19} \mathrm{~N}_{\mathrm{o}} \mathrm{K}_{\mathrm{o}}$ & 0.00 & 1.67 & 6.67 & 10.17 & 10.17 \\
\hline $\mathrm{G}_{19} \mathrm{~N}_{1} \mathrm{~K}_{1}$ & 0.00 & 0.00 & 0.00 & 5.00 & 5.00 \\
\hline $\mathrm{G}_{19} \mathrm{~N}_{1} \mathrm{~K}_{2}$ & 0.00 & 0.00 & 0.00 & 0.00 & 0.00 \\
\hline $\mathrm{G}_{19} \mathrm{~N}_{1} \mathrm{~K}_{3}$ & 0.00 & 0.00 & 0.00 & 3.33 & 3.33 \\
\hline $\mathrm{G}_{19} \mathrm{~N}_{2} \mathrm{~K}_{0}$ & 0.00 & 3.33 & 5.00 & 6.75 & 6.75 \\
\hline $\mathrm{G}_{19} \mathrm{~N}_{2} \mathrm{~K}_{1}$ & 0.00 & 0.00 & 1.67 & 1.67 & 1.67 \\
\hline $\mathrm{G}_{19} \mathrm{~N}_{2} \mathrm{~K}_{2}$ & 0.00 & 0.00 & 0.00 & 0.00 & 0.00 \\
\hline $\mathrm{G}_{19} \mathrm{~N}_{2} \mathrm{~K}_{3}$ & 0.00 & 0.00 & 1.67 & 6.75 & 6.75 \\
\hline $\mathrm{G}_{19} \mathrm{~N}_{3} \mathrm{~K}_{\mathrm{o}}$ & 1.67 & 3.42 & 10.09 & 13.79 & 13.79 \\
\hline $\mathrm{G}_{19} \mathrm{~N}_{3} \mathrm{~K}_{1}$ & 0.00 & 0.00 & 3.33 & 10.17 & 10.17 \\
\hline $\mathrm{G}_{19} \mathrm{~N}_{3} \mathrm{~K}_{2}$ & 0.00 & 0.00 & 1.67 & 11.84 & 11.84 \\
\hline $\mathrm{G}_{19} \mathrm{~N}_{3} \mathrm{~K}_{3}$ & 0.00 & 0.00 & 1.67 & 10.09 & 10.09 \\
\hline $\mathrm{G}_{20} \mathrm{~N}_{0} \mathrm{~K}_{\mathrm{o}}$ & 3.333 & 6.84 & 10.17 & 21.28 & 21.28 \\
\hline $\mathrm{G}_{20} \mathrm{~N}_{0} \mathrm{~K}_{1}$ & 0.00 & 0.00 & 0.00 & 5.00 & 5.00 \\
\hline $\mathrm{G}_{20} \mathrm{~N}_{0} \mathrm{~K}_{2}$ & 0.00 & 0.00 & 3.33 & 6.84 & 6.84 \\
\hline $\mathrm{G}_{20} \mathrm{~N}_{0} \mathrm{~K}_{3}$ & 0.00 & 3.33 & 6.84 & 10.17 & 10.17 \\
\hline $\mathrm{G}_{20} \mathrm{~N}_{1} \mathrm{~K}_{0}$ & 0.00 & 1.67 & 5.00 & 8.33 & 8.33 \\
\hline $\mathrm{G}_{20} \mathrm{~N}_{1} \mathrm{~K}_{1}$ & 0.00 & 0.00 & 0.00 & 3.33 & 3.33 \\
\hline $\mathrm{G}_{20} \mathrm{~N}_{1} \mathrm{~K}_{2}$ & 0.00 & 0.00 & 0.00 & 1.68 & 1.68 \\
\hline $\mathrm{G}_{20} \mathrm{~N}_{1} \mathrm{~K}_{3}$ & 0.00 & 3.33 & 3.33 & 8.51 & 8.51 \\
\hline $\mathrm{G}_{20} \mathrm{~N}_{2} \mathrm{~K}_{0}$ & 1.67 & 3.42 & 6.75 & 15.63 & 15.63 \\
\hline $\mathrm{G}_{20} \mathrm{~N}_{2} \mathrm{~K}_{1}$ & 0.00 & 0.00 & 0.00 & 8.33 & 8.33 \\
\hline $\mathrm{G}_{20} \mathrm{~N}_{2} \mathrm{~K}_{2}$ & 0.00 & 0.00 & 0.00 & 1.67 & 1.67 \\
\hline $\mathrm{G}_{20} \mathrm{~N}_{2} \mathrm{~K}_{3}$ & 0.00 & 0.00 & 0.00 & 3.33 & 3.33 \\
\hline $\mathrm{G}_{20} \mathrm{~N}_{3} \mathrm{~K}_{0}$ & 0.00 & 3.33 & 10.17 & 19.43 & 19.43 \\
\hline $\mathrm{G}_{20} \mathrm{~N}_{3} \mathrm{~K}_{1}$ & 0.00 & 0.00 & 3.33 & 15.19 & 15.19 \\
\hline $\mathrm{G}_{20} \mathrm{~N}_{3} \mathrm{~K}_{2}$ & 3.33 & 3.33 & 8.51 & 12.02 & 12.02 \\
\hline $\mathrm{G}_{20} \mathrm{~N}_{3} \mathrm{~K}_{3}$ & 1.67 & 6.75 & 8.61 & 15.63 & 15.63 \\
\hline LSD (0.05) & 2.07 & 4.22 & 4.14 & 5.15 & 4.95 \\
\hline $\operatorname{LSD}(0.01)$ & 2.76 & 5.61 & 5.51 & 6.86 & 6.58 \\
\hline
\end{tabular}

\section{CONCLUSION}

The storability of garlic bulb in this experiment was found significantly influenced by garmplasm, nitrogen and potassium during storage period. The highest percentage of insect infested bulbs (9.77) were founded in accession $G_{20}$ whereas the lowest percentage of insect infested bulbs (6.80) was found in accession $\mathrm{G}_{19}$. At 180 days of storage, the bulbs grown with $300 \mathrm{~kg} / \mathrm{ha}$ showed the maximum percentage of insect infested bulbs (13.52) while the minimum percentage of insect infested bulbs (5.04) was found at $100 \mathrm{~kg} \mathrm{~N} / \mathrm{ha}$. The bulbs raised without potassium $\left(0 \mathrm{~kg} \mathrm{~K} \mathrm{~K}_{2} \mathrm{O} / \mathrm{ha}\right)$ showed 
maximum percentage insect infected bulbs (13.43) whereas the minimum percentage of insect infested bulbs (4.46) was observed in the application of $200 \mathrm{~kg} \mathrm{~K}_{2} \mathrm{O} / \mathrm{ha}$. The maximum percentage of insect infested bulbs (21.28) was observed from the combination of accession $\mathrm{G}_{20}$ with $0 \mathrm{~kg} \mathrm{~N} / \mathrm{ha}$ and $0 \mathrm{~kg} \mathrm{~K}{ }_{2} \mathrm{O} / \mathrm{ha}$, whereas the minimum percentage was obtained from $\mathrm{G}_{19}$ with $100 \mathrm{~kg} \mathrm{~N} / \mathrm{ha}$ and $200 \mathrm{~kg}$ $\mathrm{K}_{2} \mathrm{O} / \mathrm{ha}$ and $\mathrm{G}_{19}$ with $200 \mathrm{~kg} \mathrm{~N} / \mathrm{ha}$ and $2000 \mathrm{~kg} \mathrm{~K} 2 \mathrm{O} / \mathrm{ha}$.

\section{Compliance with ethical standards}

The author thank to BAU, Mymensingh, Bangladesh for funding and conducting the research.

\section{Disclosure of conflict of interest}

The authors declare the absence of a conflict of interest.

\section{REFERENCES}

1. W. Simon ; The Origin and Distribution of Garlic. USDA Vegetable Crops Research Unit, USA,2001, 1-3.

2. J.M. Kigori, M.D. Magaji and A.I. Yakudu; Productivity of two garlic (Allium sativum L.) cultivars as affected by different levels of nitrogenous and phosphorus fertilizers in Sokoto, Nigeria. Proceeding of 41st Annual Conference on Bulletin of the Science Association of Nigeria, Usmanu Danfodiyo University, Sokoto,2005.

3. W.M. Randle; Increasing nitrogen concentration in hydroponic solution affects onion flavor and bulb quality. J. Amer. Soc. Hort. Sci., 2000, 125: 254-259.

4. M.M. Rashid (1996). Bangladesher Sabji (in Bangali), Bangla Academy, Dhaka, 1996,406.

5. BBS. Statistical Pocket Book of Bangladesh. Bangladesh Bureau of Statistics, Stat. Div., Minist. Planning, Govt. People's Rep. Bangladesh, 2017, 143-145.

6. Y. Zhou, D. Wang, J. Zhu , Q. Liu and M.X. Fan ; The role of sulfur fertilizers in balanced fertilization. In: L.J. De Kok and E. Schnug (eds.), Proceedings of the 1st Sino-German Workshop on Aspects of Sulfur Nutrition of Plants 23-27 May 2004 in Shenyang, China, Landbauforschung Völkenrode, Special Issue,2005,283:171-176.

7. M.B. Raja and K.M. Khokar; Post-harvest horticulture technology and its future prospects (pp: 265-277), Proceedings of First Int'l. Horticulture Seminar, 09-11 Jan., 1992. PARC, Islamabad.

8. M. Iqbal ; Type and extend of post-harvest losses in horticultural commodities on Pakistan (pp:33-42) In: Proceedings of National Conference on post-harvest technology of horticulture commodities. 10-12 Sept., 1996, Quetta.

9. N. Amiruzzaman ; Post harvest handling and processing of hyacinth bean and hyacinth bean and vegetables. In: Kitchen Gardening and Homestead productive Activities.CIRDAP Action Research Series No. 11. p.22,1990.

10. A.A. Kader (1992). Postharvest Technology of Horticultural Crops. 2nd ed. University of California,1992. 
11. Y. Nai-hua, Z. Dingguo and J. Wang; Phosphorus and Potassium Nutrient Management for Vegetable Soils in Shanghai and Guangdong. In: Donald L. Armstrong (Ed.), Better Crops International, 1998,12(1):1.

12. B. Chung; Irrigation and bulb onion quality. Acta Horticulturae, 1989,247: 233-237.

13. J. Hussien ; Influence of nitrogen and maleic hydrazide on the keeping quality and subsequent establishment of shallot. M.Sc thesis. 1996,pp. 11-13.

14. J.L. Brewster; Onions and other vegetable Alliums. CAB International, Wallingford, $\mathrm{UK}, 1994$.

15. A.S. Mohd, S.S. Rajat Tomar and K.K. Sharma; Effect of nitrogen and potassium on the growth and yield of garlic. J. Potassium Res.,1994, 10(4): 338-342.

16. D.P. Verma, B.R. Sharma, A.P.S. Chadha, H.K. Bajpai and U.P.S. Bhadauria ; Response of garlic (Allium sativum L.) to nitrogen, phosphorus and potassium levels. Plant Sci., 1996,9(2): $37-41$.

17. L.G. Lujiu, Z. Xisheng, X. Qingsong and LZ. Hongmin; Balanced fertilization increases garlic yield in Anhui. Better Crops,2004, 88(4): 30- 35.

18. H.A. El- Sayed and A.H.A. El Morsy; Response of productivity and storability of garlic (Allium sativum L.) to some potassium levels and foliar spray with mepiquat chloride (PIX). Inter. Res. J. Agric. Sci. and Soil Sci., 2012,2(7): 298-305.

19. T. Kato, M Yamagata and S. Tsukahara ; Nitrogen nutrition, its diagnosis and postharvest bulb rot in onion plant. Bull. Shikoku Nat. Agric. Exp. Station,1987, 48: 26-49.

20. E.W. Hewett ; An overview of postharvest factors influencing postharvest quality of horticultural products. International Journal of Postharvest Innovation,2006, 1: 4- 15.

\section{Corresponding author: Md. Shamim;}

Additional Deputy Director (Crop) Dinajpur District, Department of Agricultural Extension, Ministry of Agriculture, Govt. of the People's Republic of Bangladesh;

Online publication Date: 04.03.2019 